Jap. J. M. Sc. \& Biol., 11, 169-181, 1958

\title{
THE GROWTH OF HERPES SIMPLEX VIRUS IN ONE-DAY EGGS UNDER ANAEROBIC INCUBATION, WITH PRETREATMENT OF CHILLING OR WITH ADDITION OF CYANIDE*
}

\author{
HIROKAZU TANIGUCHI \\ Department of Virology \& Rickettsiology, National \\ Institute of Health, Tokyo \\ (Received: June 17th, 1958)
}

The demonstration by Yoshino (1956) that the 1-day old hen's egg was capable of growing herpes simplex virus extended the usefulness of fertile hen's eggs in virology, and subsequent reports from this and other laboratories testified that the 1-day egg was one of the most useful hosts for experimental infection of rabies (Yoshino, Kuma, Kondo and Kitaoka, 1956), vaccinia (Oya, 1956), variola (Oya, 1956), Japanese B encephalitis (Matumoto, 1957), Rift Valley fever (Matumoto, 1956), dengue (Nakagawa and Shingu, 1958) and canine distemper viruses (Kaneko and Shibuki, 1958; Fujie and Sawada, personal communication).

In the above-cited report, Yoshino (1956) described a technic by which egg-white of infected 1-day eggs was replaced with saline, stating that a considerable extent of viral release from blastodermal cells into saline was observed. Detailed studies using this technic (Yoshino and Taniguchi, 1957) indicated that this culture method could be regarded as a new type of tissue culture. One of the most interesting observations in these studies was that 1-day eggs so treated showed markedly restricted embryonic development while blastodermal cells grew almost normally on the surface of the yolk sac. This trend of independency between the embryonic and blastodermal developments was observed not only in eggs infected before egg-white replacement but also in the case of egg-white replacement of uninfected 1-day eggs.

This fact seemed to imply that the embryo of the 1-day egg is vulnerable to such a mechanical treatment as egg-white replacement whereas the blastoderm surrounding it is quite resistant to the same treatment. Further evidence to support this interpretation was obtained in an experiment (Yoshino and Taniguchi, unpublished) in which 1-day eggs were egg-white-replaced and incubated

* This work was aided in part by a research grant supplied to our Institute from the Rockefeller Foundation, U.S. A.

谷口博一（国立予防衛生研究所リケッチアウイルス部） 
for varying periods prior to infection with herpes virus. Thereby, the blastodermal cells covering the yolk sac retained their virus-growing capacity for at least 4 weeks without any appreciable reduction. These results suggested that the conditions essential to embryonic development might not necessarily apply to growth of blastodermal cells, and there might possibly exist certain conditions under which the embryonic development could be suppressed while the blastodermal cells could multiply independently retaining virus-growing ability.

Hence, search has been made for such conditions, and it was eventually found that air-tight sealing in liquid paraffin, chilling or addition of cyanide could produce the desired conditions. As a result of this study, the blastodermal cells turned out to be by far more resistant to these treatments than the embryonic cells or other known animal cells. The purpose of this report is to summarize the results of all these experiments.

\section{Materials AND Methods}

Virus: The HF strain used in the present work has been maintained through egg passages by the chorioallantoic inoculation of 12-day eggs. The 406th to 414th passages were employed. The method of passage and preparation of seed virus for experiments were stated previously (Yoshino and Taniguchi, 1956). In brief, the passage was made by infecting 12-day eggs' chorioallantoic membranes (CAM) and harvesting the CAM's after $40-48$ hours' incubation at $35^{\circ} \mathrm{C}$. The $10^{-0}$ seed virus for each experiment means a $20 \%$ emulsion of infected CAM's. The CAM emulsion as well as its dilutions was prepared in $0.1 \%$ yolk-saline buffered at $\mathrm{pH} 7.2$ with $0.01 \mathrm{M}$ phosphate buffer.

$P F U$ (pock-forming units) titration: This was also detailed in our previous publication (Yoshino and Taniguchi, 1956). In each titration, four 12-day eggs were used per dilution. Titration results were sometimes obscured by unproportional distribution of pock numbers over two or more consecutive dilution groups or by appearance of many non-specific lesions on CAM's, and such results were designated as "obscure". When examining viral quantities in eggs, the whole contents of eggs were homogenized in a Waring blendor at $0^{\circ} \mathrm{C}$ for 3 minutes and the resulting homogenates were titrated for PFU. Viral quantities were expressed by the total PFU contained per egg, taking $43 \mathrm{cc}$ as the average volume of an egg. Each material titrated was checked for bacterial sterility duplicately with thioglycollate medium.

1-day eggs: Eggs freshly delivered were collected and preincubated at $37^{\circ} \mathrm{C}$ for 24 hours. Eggs from too young mothers were not used, since such eggs showed comparatively high incidence of non-specific death during subsequent incubation. After this pre-incubation, it was easy to differentiate fertile from non-fertile eggs, because fertile ones showed by candling a dark spot (blastodermal center) in the middle of yolk sac shadow. Fertile eggs thus selected were treated in various manners as detailed in the text. When virus inoculation was made, special care was taken to introduce the inoculum of $0.2 \mathrm{cc}$ into the yolk sac at a site very near, but not directly through, the blastodermal center. For this purpose, the method of 1-day egg inoculation previously developed for titration of rabies virus (Yoshino, Kondo, Kuma and Kitaoka, 1956) was employed, unless otherwise stated. Incubation of eggs, with or without viral infection, were carried out at $37^{\circ} \mathrm{C}$ in all cases. Unless subjected to liquid paraffin sealing, eggs were rotated 12 times a day on automatically moving egg-supports.

Anaerobic incubation of eggs: Eggs were candled and contour of air sac was marked with a pencil. Inside this mark another circular mark paralleling it was 
drawn, and a rotating carborundum disc was run along the inner circular mark to cut a groove in the shell. After sterilizing the shell surface with $70 \%$ alcohol, the shell disc over the air sac was carefully removed. Then, a few drops of melted paraffinvaseline were added to the exposed air sac to cover the shell membrane, special care being taken thereby not to form air bubble under the seal. (When anaerobic incubation preceded virus infection, this sealing was done after the infection.) Eggs thus prepared were placed each in a jar containing a sufficient volume of liquid paraffin, which had been sterilized by autoclaving at $15 \mathrm{lb}$ for 20 minutes, to submerge the egg in it for airtight sealing. (Fig. 1) For incubation, the jar was placed in the $37^{\circ} \mathrm{C}$ incubator.

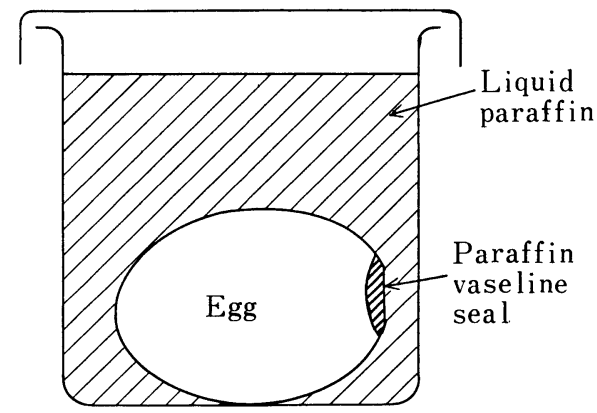

Fig. 1. Anaerobic incubation of the 1-day egg.

\section{RESULTS}

\section{Growth of Virus in Intact (Aerobic) and Liquid Paraffin Sealed (Anaerobic) 1-Day Eggs}

As a control for all the experiments hereafter described, it was necessary to know the growth pattern of HF virus after inoculation of 1-day eggs without any special treatment. Therefore, the following experiment was performed at first. Fifteen fertile 1-day eggs were inoculated with $10^{-3}$ dilution of a seed virus suspension and incubated at $37^{\circ} \mathrm{C}$. After 1,2 and 5 days, five eggs were randomly selected each time and examined individually for tissue changes and viral multiplication. Their embryonic development was hardly recognized but the blastoderm was seen expanding almost normally on the surface of the yolk sac with the passage of time. The result of titration for viral quantities in individual eggs is plotted with circles in Fig. 2.

There was only a slight degree of titer fluctuation among individual eggs tested, especially in the initial stage of cultivation, and a marked viral titer increase was seen already at the end of 24 hours. The 2nd and 5th day titers were almost equal, indicating that the peak titer was reached perhaps some time between 24th and 48th hour following the infection. These features of viral growth were quite similar to those in the egg-white-replaced 1-day eggs previously studied (Yoshino and Taniguchi, 1957).

Then, experiments with anaerobic incubation were planned. Before testing whether or not 1-day eggs under such conditions could grow virus, it was a 


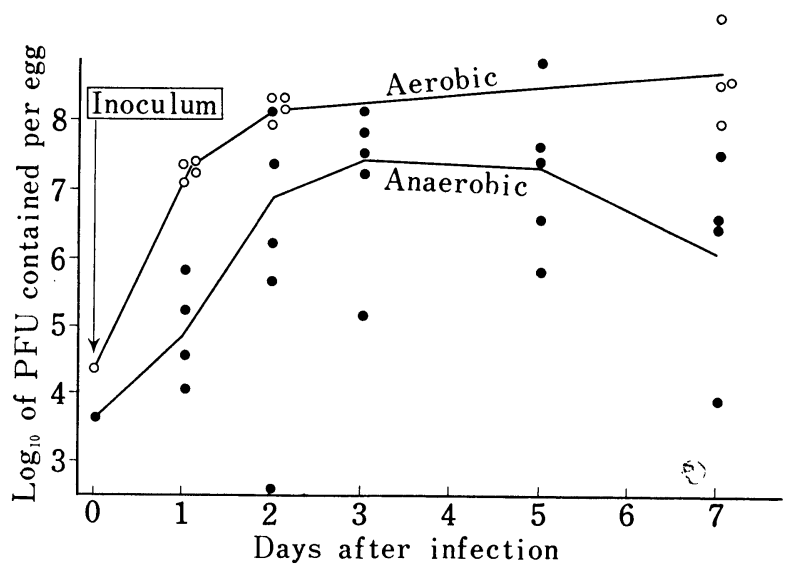

Fig. 2. Growth of HF virus in 1-day eggs under aerobic or anaerobic incubation.

Eggs which showed obscure titration results are omitted from this presentation. For definition of obscure titration results, see Methods.

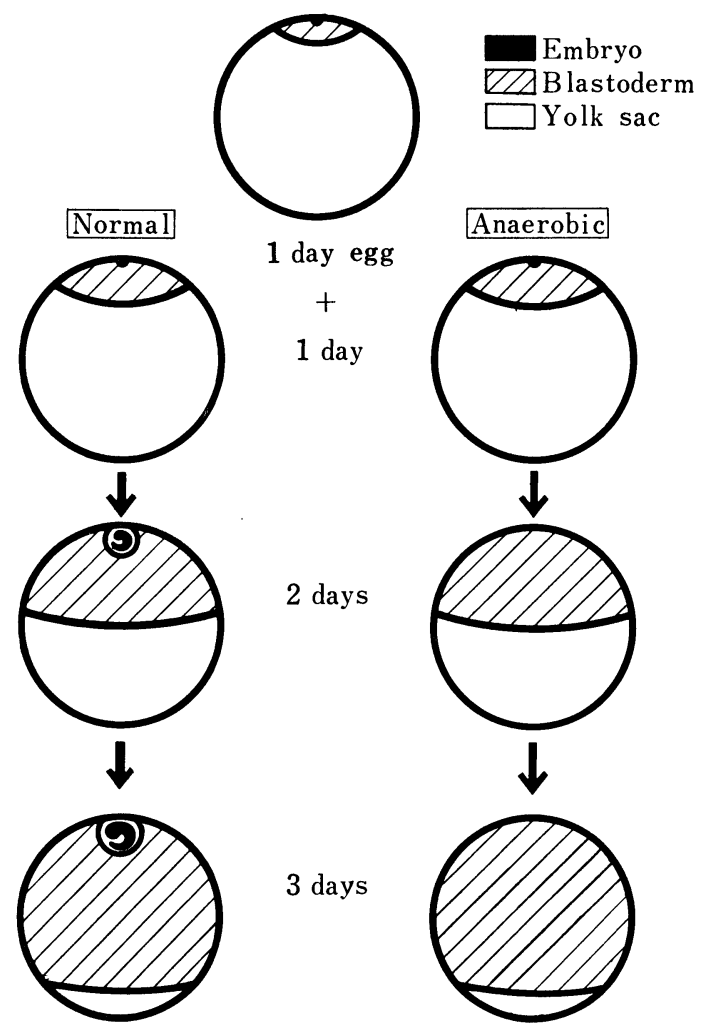

Fig. 3. A scheme of the tissue developments in the 1-day egg under aerobic and anaerobic conditions. (Without virus). 
prerequisite to it to observe what changes would be brought about by this treatment of uninfected 1-day eggs. Hence, 15 fertile 1-day eggs were subjected to liquid paraffin sealing, as described under Methods, and incubated at $37^{\circ} \mathrm{C}$. At daily intervals, 5 eggs were randomly selected and opened for examination of tissue changes. It was found that the anaerobic incubation was extremely unfavorable for development of the embryo but growth of the blastodermal cells was little affected by this treatment (Fig. 3). Namely, the embryos of these eggs showed no appreciable enlargement at all, whereas their blastoderms gradually expanded on the surface of the yolk sac almost normally until finally the surface of the yolk sac was entirely covered by the blastodermal cell growth on the 3rd day. At each time interval from the initiation of anaerobic incubation, the five eggs examined revealed quite uniform blastodermal growth.

From this result, it was expected that viral multiplication would occur in such air-tightly sealed 1-day eggs, and the following experiment was then designed. A number of fertile 1-day eggs were given $10^{-3}$ dilution of a seed virus suspension, then placed in liquid paraffin filled jars as in the preceding experiment and incubated at $37^{\circ} \mathrm{C}$. At intervals, 5 eggs were randomly chosen and examined for tissue changes and viral quantities individually. Tissue changes were again quite similar to those encountered in the preceding experiment, in that the blastodermal cell growth was almost normal despite complete suppression of embryonic development. The titration result of this experiment is illustrated with dots in Fig. 2 for the sake of comparison with the viral growth under aerobic incubation.

It can be seen that the viral multiplication under anaerobic conditions was characterized by a wide fluctuation of titers among similarly treated eggs, the maximum titer being almost equal to that of the aerobic incubation curve. It is also seen in Fig. 2 that the anaerobic incubation retarded viral growth within the 1st day.

It was then desired to see how long the eggs could retain virus-growing ability under the anaerobic conditions. Therefore, in the next experiment, 1-day eggs were incubated in liquid paraffin filled jars for varying periods prior to virus inoculation. Before infection, the eggs were cleaned with water and then with $70 \%$ alcohol to remove liquid paraffin off the shell. In this particular experiment, it was hard to visualize the blastodermal center by candling, because the blastoderms of these eggs had undergone a marked change in size by the time of virus inoculation; therefore, for injection of virus, the eggs were placed horizontally at $37^{\circ} \mathrm{C}$ for about one hour, keeping the shell slit upward with slight inclination from the vertical diameter, and then a 7-mm needle was shot blindly through the slit into the yolk sac. After injection, they were incubated aerobically and after 5 more days titrated for virus contents. This time, titration was made on a pool of 3 eggs randomly selected from each group.

It can be observed that the virus-growing ability of the blastodermal cells was reduced gradually under the anaerobic incubation until finally it was lost 
Table 1. The effect of anaerobic incubation prior to infection of 1-day eggs upon their virus-growing ability

\begin{tabular}{ccc}
\hline $\begin{array}{c}\text { Anaerobic incubation } \\
\text { after 1 day's } \\
\text { pre-incubation }\end{array}$ & $\begin{array}{c}\text { Virus given } \\
\text { per egg }\end{array}$ & $\begin{array}{c}\text { Viral yield per egg } \\
\text { after 5 more days } \\
\text { aerobic incubation }\end{array}$ \\
\hline days & $4.0 \times 10^{4}$ & PFU \\
0 & $"$ & $8.6 \times 10^{7}$ \\
3 & $"$ & $1.0 \times 10^{7}$ \\
5 & $"$ & $2.1 \times 10^{5}$ \\
7 & $"$ & $<8.6 \times 10^{3}$ \\
14 & $"$ & $<8.6 \times 10^{3}$ \\
\hline
\end{tabular}

almost completely after 7 days. Another preliminary test showed that when the 24 hours' preincubation was done anaerobically no appreciable change was observed in the blastodermal cell growth during that period. Then arose a question of whether or not such anaerobically preincubated 1-day eggs could retain their virus-growing ability, and the following experiment was carried out.

Three groups of 5 fresh eggs were preincubated for 24 hours either aerobically or anaerobically, then inoculated with a pertinent dilution of a seed virus suspension and incubated subsequently under aerobic or anaerobic conditions. After 5 days, each group of eggs was pooled, homogenized together and titrated. As revealed in Table 2, there was no significant difference among the 3 groups.

Table 2. The effect of anaerobic pre-incubation and/or anaerobic incubation after infection of 1-day eggs upon their virus-growing ability

\begin{tabular}{|c|c|c|c|}
\hline $\begin{array}{l}\text { Pre-incubation } \\
\text { for } 24 \text { hours }\end{array}$ & $\begin{array}{l}\text { Virus given } \\
\text { per, egg }\end{array}$ & $\begin{array}{l}5 \text { days' incubation } \\
\text { after infection }\end{array}$ & $\begin{array}{l}\text { Viral yield } \\
\text { per egg }\end{array}$ \\
\hline & $\mathrm{PFU}$ & & $\mathrm{PFU}$ \\
\hline Anaerobic & $3.6 \times 10^{3}$ & Aerobic & $5.5 \times 10^{5}$ \\
\hline Anaerobic & " & Anaerobic & $4.0 \times 10^{6}$ \\
\hline Aerobic & , & Anaerobic & $6.9 \times 10^{6}$ \\
\hline
\end{tabular}

\section{Experiments with Chilling of 1-Day Eggs}

The experimental results so far presented have provided evidences for the fact that resistance against anaerobic conditions differ greatly between the embryo and blastodermal cells of the 1-day egg. Since no enlargement of the embryo took place under anaerobic incubation of 1-day eggs even without infection, the virus may have been reproduced under such conditions only in the growing blastodermal cells. However, one might postulate that the role of viral reproduction was played by the seemingly dead embryo and the blastodermal cells were not responsible for the viral growth. Therefore, in order to elucidate the role of the blastodermal cells in viral reproduction, various lines of investigation have been worked out. 
The first attempt for this purpose was the use of chilling procedure. At first, effects of chilling 1-day eggs in an ice box was tested. Six groups of 20 1-day eggs were placed in the ice box for varying periods of time stated in Table 3 and then transferred to the $37^{\circ} \mathrm{C}$ incubator. A control group of 20 1 -day eggs receiving no chilling was included. After 5 days' reincubation, all the eggs were opened and examined for tissue changes.

With this treatment, unlike the anaerobic incubation, individual differences among equally treated eggs were observed in certain groups with respect to the tissue appearance, and they were grouped into the following four categories: (1) normally developing eggs (Emb. + , Bla. + , live), (2) eggs which developed normally but died before the 5 th day (Emb. + , Bla. + , dead), (3) eggs showing expansion of blastoderms but no enlargement of embryos (Emb. -, Bla. + ) and (4) eggs showing neither embryonic nor blastodermal enlargement (Emb. -, Bla. -). The result of this test is recorded in Table 3.

Table 3. Effects of chilling of 1-day eggs upon their potentials for embryonic and blastodermal developments

\begin{tabular}{|c|c|c|c|c|c|}
\hline \multirow[b]{2}{*}{ Chilling } & \multirow{2}{*}{$\begin{array}{l}\text { Number of } \\
\text { eggs used }\end{array}$} & \multicolumn{4}{|c|}{ Number of eggs categórized as } \\
\hline & & $\begin{array}{l}\text { Emb. + live } \\
\text { Bla. + }\end{array}$ & $\begin{array}{l}\text { Emb. }+ \text { dead } \\
\text { Bla. + }\end{array}$ & $\begin{array}{l}\text { Emb. - } \\
\text { Bla. }+\end{array}$ & $\begin{array}{l}\text { Emb. - } \\
\text { Bla. - }\end{array}$ \\
\hline \multicolumn{6}{|c|}{ days } \\
\hline 0 & 20 & 20 & 0 & 0 & 0 \\
\hline 1 & 20 & 18 & 1 & 0 & 1 \\
\hline 3 & 20 & 12 & 7 & 1 & 0 \\
\hline 5 & 20 & 6 & 11 & 3 & 0 \\
\hline 7 & 20 & 0 & 5 & 6 & 9 \\
\hline 14 & 20 & 0 & 0 & 0 & 20 \\
\hline 21 & 20 & 0 & 0 & 0 & 20 \\
\hline
\end{tabular}

It was noticed that after 5 to 7 days' chilling some eggs retained the potential for blastodermal growth but completely lost the potential for embryonic enlargement, and that both potentials were lost after chilling for more than 14 days. That is to say, the embryo was damaged by chilling earlier than, and not concomitantly with, the damage of the blastodermal cells.

In the next experiment, 10 fertile 1-day eggs were chilled in the ice box for one week, then equally infected with $10^{-3}$ dilution of a seed virus and transferred to the $37^{\circ} \mathrm{C}$ incubator. After 5 days' reincubation, their viral contents were examined individually, and the result is presented in Table 4.

Both the embryo and blastoderm were restricted in their growth to a great extent, and in 3 eggs showing little or no embryonic or blastodermal growth as well as in one which showed only blastodermal expansion a considerable extent of viral reproduction could be observed. However, this fact can not readily be interpreted as indicating that virus multiplication occurred in cells deprived of growth potentiality, because from the result of the preceding experiment 
Table 4. Growth of HF virus in 1-day eggs pre-treated with chilling for 1 week

\begin{tabular}{|c|c|c|c|c|}
\hline \multirow{2}{*}{ Egg No. } & \multirow{2}{*}{$\begin{array}{l}\text { Virus given } \\
\text { per egg }\end{array}$} & \multicolumn{2}{|c|}{$\begin{array}{l}\text { Enlargement of tissue } \\
\text { after } 5 \text { days }\end{array}$} & \multirow{2}{*}{$\begin{array}{l}\text { Viral yield } \\
\text { per egg }\end{array}$} \\
\hline & & Embryo & Blastoderm & \\
\hline & \multicolumn{2}{|c|}{ PFU } & & PFU \\
\hline 1 & $2.5 \times 10^{4}$ & - & + & $1.7 \times 10^{8}$ \\
\hline 2 & " & - & \pm & $1.2 \times 10^{7}$ \\
\hline 3 & " & - & - & $2.7 \times 10^{5}$ \\
\hline 4 & " & - & - & $2.1 \times 10^{5}$ \\
\hline 5 & ” & - & - & 0 \\
\hline 6 & " & - & - & 0 \\
\hline 7 & " & - & - & 0 \\
\hline 8 & " & - & - & 0 \\
\hline 9 & " & - & - & 0 \\
\hline 10 & , & - & - & 0 \\
\hline
\end{tabular}

of Table 3 one can expect that 7 days' chilling would result in loss of potentials for embryonic and blastodermal developments in $75 \%$ and $45 \%$ of eggs respectively. Therefore, it might be conceivable that those eggs which showed virus growth in this experiment had possessed the potential for embryonic or blastodermal expansion at the time of virus inoculation and the effects of pre-chilling coupled by the effects of viral infection induced such an increased restriction of cell growth.

This experiment, however, did not give a decisive answer to the question of whether or not the potential for growth retained by the blastoderm was responsible for the viral reproduction. Therefore, another means by which this question would be solved was looked for.

\section{Experiments with Addition of Cyanide into 1-Day Eggs}

In the next experiments, addition of cyanide was attempted instead of chilling of 1-day eggs. At first, effects of different concentrations of cyanide upon uninfected 1-day eggs were tested as follows. Five groups of 20 fertile 1-day eggs were inoculated with aqueous solution of $\mathrm{NaCN}$ of different concentrations, from $0.1 \mathrm{M}$ to $0.0008 \mathrm{M}$, or with control distilled water in the amount of $0.2 \mathrm{cc}$ in the same manner as inoculation of virus, and placed in the ice box for 3 days to permit dispersion of cyanide throughout the egg. Then, all the eggs were transferred to the $37^{\circ} \mathrm{C}$ incubator. After 5 days, they were opened and examined for tissue changes. The result is demonstrated in Table 5, which indicates that individual differences among equally treated eggs existed in all the groups, and that the four categories of tissue appearance observed previously in the experiment of chilling (Table 3) all appeared in such an order that with increasingly more amount of cyanide added the 1-day eggs 
Table 5. Effects of combined treatment of 1-day eggs with different concentrations of $\mathrm{NaCN}$ and chilling for 3 days upon their potentials for embryonic and blastodermal developments

\begin{tabular}{|c|c|c|c|c|c|}
\hline \multirow{2}{*}{$\begin{array}{c}\mathrm{NaCN} \\
\text { Concentration } \\
\text { in } 0.2 \mathrm{cc} \\
\text { inoculum }\end{array}$} & \multirow[b]{2}{*}{$\begin{array}{l}\text { Number of } \\
\text { eggs used }\end{array}$} & \multicolumn{4}{|c|}{ Number of eggs categorized as } \\
\hline & & $\begin{array}{l}\text { Emb. + live } \\
\text { Bla. + }\end{array}$ & $\begin{array}{l}\text { Emb. + dead } \\
\text { Bla. + }\end{array}$ & $\begin{array}{l}\text { Emb. - } \\
\text { Bla. + }\end{array}$ & $\begin{array}{l}\text { Emb. - } \\
\text { Bla. - }\end{array}$ \\
\hline M & 20 & 0 & 0 & 4 & 16 \\
\hline 0.02 & 20 & 2 & 1 & 9 & 8 \\
\hline 0.004 & 20 & 6 & 11 & 3 & 0 \\
\hline 0.0008 & 20 & 6 & 5 & 7 & 2 \\
\hline $\begin{array}{l}\text { Control } \\
\text { distilled } \\
\text { water }\end{array}$ & 20 & 6 & 8 & 3 & 3 \\
\hline
\end{tabular}

were damaged in two sequences, $i$.e. firstly the embryo lost its potential for growth and then did the blastodermal cells.

From this result, it is to be expected that, if 1-day eggs are treated with $0.1 \mathrm{M} \mathrm{NaCN}$ for 3 days in the cold, their potential for embryonic growth will be lost completely but their potential for growth of blastodermal cells will remain unaltered in more or less $20 \%$ of the eggs. In the next experiment, therefore, 10 fertile 1-day eggs were given $0.2 \mathrm{cc}$ of $0.1 \mathrm{M} \mathrm{NaCN}$, placed in the ice box for 3 days and then inoculated with a $10^{-3}$ diluted seed virus. Then they were returned to the $37^{\circ} \mathrm{C}$ incubator and after 5 days examined for tissue changes and virus titers individually. The result is recorded in Table 6.

No egg showed any recognizable growth of the embryo nor any appreciable blastodermal cell growth, except one which disclosed only equivocal blastodermal expansion. Nevertheless, 4 out of the 10 eggs possessed high titers of virus,

Table 6. Growth of HF virus in the 1-day eggs pre-treated with the addition of $0.1 \mathrm{M} \mathrm{NaCN}$ and chilling for 3 days

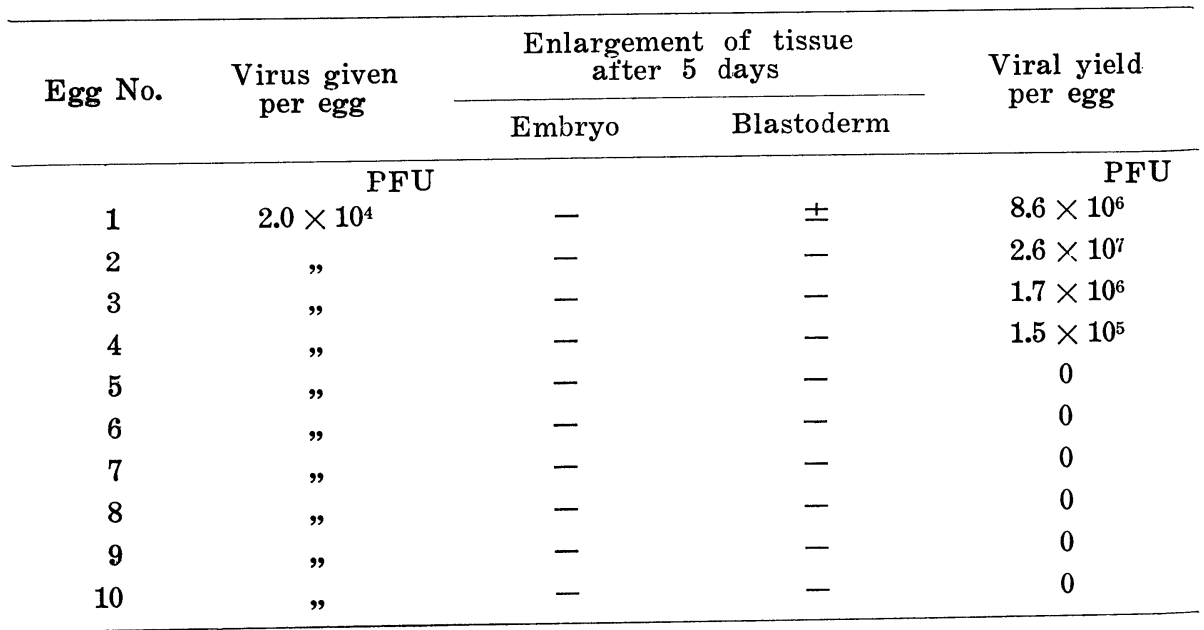


while all the others contained no detectable amount of virus. Statistically, there is no significant difference between 4 in 20 and 4 in 10 , and therefore a comparison between Tables 5 and 6 will convince one that the growth potential of the embryo itself is not essential to the viral reproduction, and the retention of the growth potential by the blastodermal cells should be responsible at least in part for the 1-day egg's capability of growing herpes virus.

\section{Discussion}

It has been generally accepted that viral growth in infected animal cells requires sufficient supply of air or oxygen. When air was replaced by $\mathrm{N}_{2}$ in the gas phase of tissue culture, viral reproduction as well as cellular respiration was reduced to a great extent (Tamm, 1956; Ackermann, 1951; Moulder et al., 1953; Pearson, 1950; Gifford et al., 1954). Thompson and Coates (1939) could grow vaccinia virus with chick embryo tissues in Maitland type tissue culture with the fluid depth of up to $115 \mathrm{~mm}$, but failed to obtain viral growth when the culture was sealed with paraffin-vaseline. In incubation of embryonated eggs too, it has been a matter of common sense to keep them under good ventilation and adequate humidity.

Nevertheless, the present experimental results clearly indicated that the blastodermal cells of the 1-day egg are exceptional to the above rule of animal cells. Namely, under anaerobic incubation which did not permit any enlargement of the embryo, growth of the blastodermal cells was little influenced and the potential for virus reproduction was retained, in some cases on a normal level, at least within a few days.

A recent report of Gifford and Syverton (1957) revealed another exception to the general rule of animal cells in the tissue culture of HeLa cells under anaerobiosis, stating that per cell yield of poliovirus under anaerobiosis was similar to that obtained by ordinary aerobic cultivation though the titer increase was somewhat retarded. In their experiments, the gas phase was replaced with $\mathrm{N}_{2}$. In our present case, only sealing of air sac and shell-outside with liquid paraffin was adopted, and therefore it is very likely that there was a residual amount of air inside the paraffin-sealed eggs.

We have now four facts to be analysed and accounted for by one principle. Firstly, anaerobic incubation of infected 1-day eggs showed marked fluctuation of virus titers reached. Secondly, 24 hours' preincubation of eggs under anaerobic conditions did not affect the blastodermal growth nor its virus-growing potential. Thirdly, anaerobic cultivation of 1-day eggs for more than a few days remarkably reduced their virus-growing potential. In addition, as stated under Introduction, our earlier experiments indicated that the egg-white-replaced 1-day eggs' blastoderms retained their virus-growing ability for at least 4 weeks. An analysis of these 4 facts would seem to point to the validity of the following explanation. 
Within the age of 1 day, an egg possesses a comparatively small number of cells, and oxygen available within the framework of egg-shell is sufficient for metabolism of the blastodermal cells, which can survive at an extremely low oxygen tension. But with such lowered supply of oxygen, the embryonic cells can no longer maintain themselves. Therefore, under the air-tight sealing with liquid paraffin, the embryonic cells die off in an early stage of incubation, while the blastodermal cells multiply independently. However, when the blastodermal expansion reaches a certain extent, the increased number of cells require oxygen supply from outside of the egg, and the metabolic activities of these cells are reduced gradually, unless the egg is aerated. Such cessation of metabolic activities of the air-tightly sealed 1-day egg appears sooner or later depending upon the amount of residual oxygen present in the egg; when this amount is too minute in the case of viral infection the blastodermal cells die before reproducing virus, whereas when residual oxygen is present in an amount just sufficient to maintain the blastodermal cells a high titer of virus can be reproduced. On the other hand, so long as placed under aerobic conditions, the blastodermal cells even when growing independent of the embryo can maintain themselves for a long time, retaining the capability of growing virus therein.

Whatever explanation may be tenable, it will remain a fact of great interest that the 1-day egg's tissue consists of two parts, embryo and blastoderm, possessing different requirements for oxygen tension. Furthermore, this difference in resistance to low oxygen tension between these two parts appeared in parallel also in their behaviors against low temperature and cyanide.

In the initial work on the 1-day egg infection with herpes virus, Yoshino (1956) avoided the risk of placing 1-day eggs at room temperature for longer than 30 minutes at a time, since lowering of temperature appeared to influence growth potential of the embryo. Although the present results proved that incubation of 1-day eggs at $0-4^{\circ} \mathrm{C}$ for one day did not appreciably harm the subsequent embryonic development, prolonged incubation at this temperature induced damage of their growth potentials in a sequence of two stages, i.e. at first the embryonic growth potential was damaged and later were the blastodermal cells.

In the case of cyanide treatment too, a higher concentration of cyanide was needed to damage growth potential of the blastodermal cells than needed for damage of growth potential of the embryo. The resistance against cyanide of the blastodermal cells seems to be also exceptional as animal cells, because the concentration of cyanide tolerated by these cells was $0.1 \mathrm{M}$. After diluted by dispersion within the egg, it may have been of the order of $10^{-3} \mathrm{M}$, which is a concentration high enough to stop cellular respiration of other animal cells such as mouse brain (Pearson, 1950) or L strain cells (Pace and Phillips, 1955). 
That the blastodermal cells are responsible for viral reproduction was shown decisively in the experiments with cyanide treatment, and less decisively in those of chilling, by the fact that the potential for virus reproduction was lost concomitantly when the potential for the blastodermal cell growth was lost. Thus, it has been established that the 1-day egg's blastodermal cells, which differ greatly from ordinary animal cells in the resistance against various physico-chemical treatments, can grow herpes virus as well.

At present, what role is played by the seemingly dead embryo, as observed in the present experiments, is not clear. The only presumption which seems permissible is that such an embryo deprived of its growth potential may not support viral multiplication. In this connection, it is of interest that when 1-day eggs were infected with vaccinia virus a titer rise was seen even after the death of the embryo (Oya, 1956). Presumably, in that case too, the blastodermal cells were actively producing virus despite the early death of the embryo.

\section{SUMMARY}

When 1-day eggs were sealed air-tightly in liquid paraffin and incubated at $37^{\circ} \mathrm{C}$, no embryonic enlargement was observed but the blastoderm expanded on the surface of the yolk sac almost normally. When 1-day eggs were infected with herpes virus and then subjected to this anaerobic incubation, viral multiplication occurred showing a wide range of titer fluctuation among individual eggs, the maximum being equal to the titer obtained by ordinary aerobic incubation. The increase of viral titer in the initial stage was slower than the growth under aerobic incubation. Anaerobic preincubation of eggs also resulted in normal development of the blastoderm possessing virus-growing potential. Under anaerobic incubation of 1-day eggs, however, the potential for virus reproduction was lost gradually until after 7 days it was diminished remarkably. Chilling of 1-day eggs in an ice box or addition of cyanide damaged their growth potentials in two stages; at first the embryo lost its growth potential and then did the blastodermal cells. So long as the blastoderm retained the growth potential, 1-day eggs treated with chilling or cyanide could grow virus to a considerable extent. It was concluded from these results that the 1-day egg's blastodermal cells, being quite different from ordinary animal cells in the resistance against various physico-chemical treatments, could grow herpes virus even when the embryo was damaged by such treatments.

The author is greatly indebted to Dr. K. Yoshino, Chief of the Rabies Division of our Department, for his excellent guidance throughout this work.

\section{REFERENCES}

ACKermanN, W. W. (1951): Concerning the relation of the krebs cycle to virus production. J. Biol. Chem., 189, 421-428.

Gifford, G. E., Robertson, H. E. \& Syverton, J. T. (1954) : Application of manometric method to testing chemical agents in vitro for interference with poliomyelitis virus synthesis. Proc. Sloc. Exper. Biol. \& Med., 86, 515-522. 
GIFFord, G. E. \& Syverton, J. T. (1957): Replication of poliovirus in primate cell cultures maintained under anaerobic conditions. Virology, 4, 216-223.

Kaneko, J. \& Shibuki, M. (1958): read before the Annual Meeting of the Society of Japanese Veterinary Medicine.

Matumoto, M. (1956): read before the Annual Meeting of the Society of Japanese Virologists.

MAтUмото, M. (1957): Inoculation de l'œuf incubé pendant vingt-quatre heures avec le virus d'encéphalite japonaise. Compt. rend. Soc. Biol., 151, 1466-1470.

Moulder, J. W., Mc CoRmack, B. R. S. \& Itatani, M. K. (1953) : Energy requirements for synthesis of feline pneumonitis virus in isolated chick embryo yolk sac. J. Infect. Dis., 93, 140-149.

NAKagawA, Y. \& Shingu, M. (1958): Studies on dengue virus XII. Inoculation of dengue virus in one-day-old hen's egg. J. Virol. 8, 118-120. (Text in Japanese, and abstracted in English in p. 160-161).

OyA, A. (1956): Growth of vaccinia and variola viruses in the one-day-old fertile hen's egg. Jap. J. M. Sc. \& Biol., 9, 293-302.

PACE, D. M. \& Phillips, H. J. (1955): Effect of cyanide on growth and respiration in Earle's strain L cells. Proc. Soc. Exper. Biol. \& Med., 90, 568-570.

Pearson, H. E. (1950): Factors affecting the propagation of Theiler's GDVII mouse encephalomyelitis virus in tissue cultures. J. Immunol., 64, 447-454.

TAMM, I. (1956): Selective chemical inhibition of influenza B virus multiplication. J. Bacteriol., $72,42-53$.

Thompson, R. L. \& Coates, M. S. (1939): The cultivation of vaccinia virus in deep columns of Maitland medium. J. Infect. Dis., 64, 105-109.

Yoshino, K. (1956): Infection of one-day-old fertile hen's egg with herpes simplex virus. J. Immunol., 76, 301-307.

Yoshino, K., Kondo, A., Kuma, N. \& Kitaoka, M. (1956): Infection of the one-dayold fertile hen's egg with rabies virus II. Application to rapid viral titration and neutralization test. Jap. J. M. Sc. \& Biol., 9, 273-282.

Yoshino, K., Kuma, N., Kondo, A. \& Kitaoka, M. (1956) : Infection of the one-dayold fertile hen's egg with rabies virus I. Growth curves and serial passages. Jap. J. M. Sc. \& Biol., 9, 259-271.

Yoshino, K. \& Taniguchi, H. (1956): Quantitative studies on the interactions between herpes simplex virus and ectodermal cell of chorioallantoic membrane of fertile hen's egg by means of the cover slip infection system I. Adsorption of virus onto cells. Jap. J. M. Sc. \& Biol., 9, 303-319.

Yoshino, K. \& TANiguchi, H. (1957): Further studies on the growth of herpes simplex virus in the egg-white-replaced one-day egg. Jap. J. M. Sc. \& Biol., 10, 257-275. 